\title{
PENGEMBANGAN PERANGKAT PEMBELAJARAN BLENDED LEARNING MODEL COOPERATIVE UNTUK MENINGKATKAN HASILBELAJAR FISIKA SMA KELAS XI
}

\author{
Rosmiati $^{1}$ \\ Budi Jatmiko 2 \\ Madlazim ${ }^{3}$ \\ 1 Mahasiswa Prodi Pendidikan Sains Pascasarjana Universitas Negeri Surabaya \\ 2 Dosen Prodi Pendidikan Sains Program Pascasarjana Universitas Negeri Surabaya \\ 3 Dosen Prodi Pendidikan Sains Program Pascasarjana Universitas Negeri Surabaya \\ e-mail: ain_maratus14@yahoo,.co.id
}

\begin{abstract}
This research is research development at developing learning material based on blended learning cooperative model. The learning material is developed using Kemp model and one group pretest-posttest design. Try out for learning material is carried out at $2^{\text {nd }}$ semester SMAN 16 Surabaya. The research subjects in grade XI IPA 2, XI IPA 3 and XI IPA 4 and the topic is thermodynamics. Data gathering uses three methods; observation, test and questionnaire. Material validity analysis is applied to analyses data. The validity involve (a) the truth of conseptual in learning material: the reabilitas of learning plans at 85,71\%, student's worksheet at 75\%, student's teks book at 77,27\%, web moodle with homepage http://fisikaunesa.net/elearning/at 86,34\% and assesment sheet for product and process test at 100\%, (b) legibility of: student's worksheet at 99\%, student's text book at 97,7\% and web moodle at 100\% in easily understood category, (c) difficulties: student's worksheet at 1,0; student's text book at 13,0; Web Moodle at 0,0; and assessment sheet in easily understood category. 2) the practicality involve: (a) realization of Learning Plans reached $100 \%$ in good category, (b) student's activity reached 89\% in good category, (c) WIFI's trouble. 3) the effectivity involve: (a) enhancement of student's achievement with N-Gain calculation: Natural Science 2 class with score 0,88, Natural Science 3 with score 0,85, Natural Science 4 with score 0,87 in high category, (b) student's response with meanin 3 in agree category. Based on the results, it can be concluded that learning material based on Blended Learning Cooperative Model to increase student's achievement in physics at senior high school grade XI is feasible.
\end{abstract}

Keywords: Blended Learning, Cooperative Model, Achievement, Senior High Students grade XI

\begin{abstract}
Abstrak: Penelitian ini adalah penelitian pengembangan yang mengembangkan perangkat pembelajaran blended learning model kooperatif. Perangkat pembelajaran dikembangkan menggunakan model Kemp dengan model ujicoba one group pretest-posttes design. Uji coba perangkat pembelajaran dilakukan pada semester genap SMAN 16 Surabaya. Penelitian ini dilakukan pada kelas XI IPA 2, XI IPA 3 dan XI IPA 4 materi termodinamika. Pengumpulan data menggunakan tiga teknik yaitu observasi, tes dan angket sedangkan analisis data menggunakan analisis validitas perangkat. Hasil penelitian dianalisis dan diperoleh beberapa temuan yaitu: 1) validitas yang meliputi: (a) kebenaran konseptual perangkat pembelajaran: RPP dengan reabilitas $85,71 \%$, LKS dengan reabilitas $75 \%$, BAS dengan reabilitas $77,27 \%$, web moodle dengan hompage http://fisikaunesa.net/elearning/ dengan reabilitas 86,34\%, dan LP untuk THB produk dan proses dengan reabilitas 100\%, (b) keterbacaan: LKS 99\%, BAS 97,7\% dan Web Moodle 100\% dengan kategori mudah dipahami (c) Kesulitan: LKS 1,0; BAS 13,0; Web Moodle 0,0; dan LP berada pada kategori mudah dipahami. 2) Kepraktisan yang meliputi: (a) Keterlaksanaan RPP mencapai 100\% berkategori baik, (b) Aktivitas siswa mencapai 89\% berkategori baik, (c) kendala jaringan WIFI. 3) Efektifitas meliputi: (a) Peningkatan hasil belajar dengan perhitungan N-Gain: IPA 2 skor 0,88, IPA 3 skor 0,85, IPA 4 skor 0,87 dengan kriteria tinggi, (b) respon siswa dengan rata-rata 3 berada pada ketegori setuju. Berdasarkan hasil temuan di atas, dapat disimpulkan bahwa perangkat pembelajaran blended learning model cooperative untuk meningkatkan hasil belajar fisika SMA kelas XI layak digunakan.
\end{abstract}

Kata-kata kunci: Blended Learning, Model cooperative, Hasil Belajar, Siswa SMA kelas XI

\section{PENDAHULUAN}

Dewasa ini perkembangan teknologi informasi komputer telah merambah dunia pendidikan. Dengan memasuki dunia on-line, guru dapat memperoleh berbagai informasi yang diperlukan untuk memenuhi kebutuhan bahan pembelajaran. Teks, foto, video, animasi dan simulasi adalah beberapa contoh media yang tersedia di situs-situs pembelajaran. Dengan memanfaatkan berbagai media tersebut, guru dapat mempresentasikan konsepkonsep IPA dalam berbagai representasi (multiple representation) yang mempermudah siswa memahami sebuah konsep. Purtadi (2011). Di Negara maju telah melakukan persiapan belajar sejak awal abad 21 dengan membentuk suatu kelompok yang diberi nama Partnership 
for 21 st century skills, yang merupakan suatu organisasi yang dibentuk pada tahun 2002 untuk memikirkan bagaimana pembelajaran sukses untuk abad 21, yaitu mengintegrasikan keterampilan abad 21 ke dalam sistem pendidikan. Salah satu dari enam unsur pembelajaran abad 21 (Partnership for 21st century skills, 2002) adalah dibahas mengenai TPACK dan blended learning (apa, mengapa, dan bagaimana) sebagai salah satu alternatif yang dapat dipilih guru untuk mempersiapkan hidup di abad 21 dengan keterampilan abad 21 (Susilo, 2011).

Berdasarkan hal tersebut, para ahli pendidikan di dunia mencoba merancang suatu basis belajar yang dapat memanfaatkan kemajuan teknologi ini untuk mengembangkan suatu proses belajar yang mengkombinasi antara penggunaan internet dengan e- learning dan pembelajaran seperti biasa yaitu melalui tatap muka (face to face) di lingkungan belajar.

Berdasarkan angket pra penelitian di SMA 16 Surabaya dilaporkan bahwa $84,70 \%$ siswa sering menggunakan internet untuk membuka facebook, twitter dan bermain game. Hanya jika ada tugas membuat makalah dari guru, baru siswa menggunakan internet untuk mencari informasi, jurnal dan artikel yang dibutuhkan. Namun, 92,30\% siswa kesulitan dalam memilih materi untuk keperluan makalah yang dimaksud. Selain itu, dilaporkan juga bahwa 99,70\% mata pelajaran tidak pernah menggunakan pembelajaran e-learning oleh karena itu 99,00\% siswa berharap adanya pembelajaran e-learning di sekolahnya. Selanjutnya berdasarkan wawancara langsung dengan guru fisika SMA Negeri 16 Surabaya, diketahui bahwa nilai rata-rata siswa kelas XI IPA semestar II ulangan harian materi pokok termodinamika pada tahun pelajaran 2011/2012 diperoleh untuk kelas XI IPA 1, XI IPA 2, XI IPA 3 dan XI IPA 4 berturut-turut diperoleh nilai rata-rata 75,19, 75,04, 75,43 dan 75,29 dengan KKM 75, terlihat bahwa nilai rata-rata siswa masih standar dan sedikit di atas KKM. Oleh karena itu perlunya pembelajaran yang dapat meningkatkan nilai rata-rata siswa di atas KKM.

Untuk menunjang, mengatasi dan membantu guru dan siswa terhadap kebutuhan sumber-sumber belajar yang lebih luas dan hasil belajar yang maksimal memerlukan suatu pendekatan pembelajaran blended learning model kooperatif menggunakan moodle yaitu suatu metode belajar mengajar yang memungkinkan tersampaikannya bahan ajar ke siswa dengan media internet, intranet atau media jaringan komputer lain. Pelaksanaan blended learning ini sudah banyak dilakukan dalam bidang pendidikan. Di sebuah Universitas Central Florida (UCF) yang mengaplikasikan blended learning ini menunjukkan bahwa blended learning dapat meningkatkan prestasi belajar. Tingkat keberhasilan yang diperoleh peserta didik lebih tinggi dari pada tatap muka (face to face) saja ataupun bebasis Web saja (Dziuban, 2004).

Blended learning adalah suatu kegiatan pembelajaran yang mengkombinasikan tatap muka di kelas dengan kegiatan belajar menggunakan media internet. Dalam penerapan mengurangi kontak langsung dengan siswa saat jam belajar di sekolah (reduce seat time). Tujuan dikembangkannya blended learning menurut Garnham (2002) mata kuliah hybrid adalah mata pelajaran yang sebagian pembelajarannya dilakukan secara online dan waktu yang biasanya digunakan dalam kelas dikurangi, tetapi tidak dihilangkan. Hoic dan Natasa dkk (2009) mendefinisikan sebagai "the thoughtful fusion of face-toface and online learning". untuk merancang ulang mata pelajaran sehingga ada kegiatan online berupa studi kasus, tutorial, latihan mandiri, simulasi atau kolaborasi kelompok online. Rooney, J. E. (2003) mengatakan bahwa mata pelajaran blended learning difokuskan untuk mengubah bentuk pembelajaran klasik sehingga siswa lebih aktif mempelajari materi pelajaran di dalam dan di luar kelas. Tujuan akhirnya adalah meningkatkan pemahaman siswa mengenai materi pelajaran yang ditunjukkan dengan meningkatkan nilai mata pelajaran yang dirancang ulang.

Moodle adalah sebuah Open Source Course Management System (CMC), yang berarti tempat belajar dinamis dengan menggunakan model berorientasi objek, juga dikenal sebagai Learning Management System (LMS) atau Virtual Leaning Environment (VLE). Moodle merupakan sebuah program aplikasi yang dapat merubah media pembelajaran ke dalam bentuk web. Aplikasi ini memungkinkan siswa untuk masuk ke dalam "ruang kelas" digital untuk mengakskes materi-materi pembelajaran. Pembelajaran blended learning model kooperatif menggunakan moodle memberikan kesempatan pada guru untuk menyajikan informasi untuk mengingat kembali tentang konsep termodinamika. Moodle juga memasukkan gambar, foto, video, phet, flash, materi, kuis dan Tanya jawab.

Makri dan Kynigos dalam Zainudin (2011) menunjukkan bentuk interaksi sosial dalam pembelajaran berbasis Web berbeda dengan interaksi sosial seperti orangorang dalam ruang kelas. Mereka menyimpulkan pembelajaran berbasis web harus didukung oleh strategi pembelajaran yang tepat. Pembelajaran kooperatif adalah solusi untuk memfasilitasi interaksi dalam suasana kelas nyata.

Di dunia pendidikan, Cooperative learning diperkenalkan melalui karya Johnson and Johnson (1992). Mereka mendefinisikan cooperative learning sebagai penggunaan kelompok kecil siswa yang terdiri atas 4-5 orang, yang bekerja sama untuk saling belajar sehingga mendapatkan hasil yang maksimal. Ini akan membantu 
efektivitas penyerapan dan pengembangan materi. Salah satu model pembelajaran kooperatif yang cocok untuk hampir seluruh mata pelajaran dan tingkat kelas adalah Student team Achievement divisions (STAD).

Model pembelajaran kooperatif STAD dengan bantuan Moodle menyediakan sarana bagi siswa dan guru atau sesama siswa untuk bekerja sama dan proses belajar mengajar (menyediakan materi pembelajaran) dapat tersimpan dalam moodle, sebagai evaluasi lebih lanjut.

\section{METODE PENELITIAN}

Penelitian ini termasuk penelitian pengembangan (developmental research) karena mengembangkan perangkat pembelajaran blended learning model cooperative pada materi pokok Termodinamika fisika SMA kelas XI. Perangkat yang dikembangkan adalah RPP, BAS, LKS, LP dan web moodle.

Pengembangan perangkat dalam penelitian ini menggunakan model (Kemp, 2007). Penggunaan model ini dalam pengembangan suatu mata pelajaran dimaksudkan agar (1) pada awal proses pembelajaran anak didik atau siswa dapat mengetahui dan mampu melakukan hal-hal yang berkaitan dengan materi pada akhir pembelajaran, (2) adanya pertautan antara tiap komponen khususnya strategi pembelajaran dan hasil pembelajaran yang dikehendaki, (3) menerangkan langkah-langkah yang perlu dilakukan dalam melakukan perencanaan desain pembelajaran.

Desain ujicoba perangkat pembelajaran dalam pengembangan perangkat ini menggunakan model pre eksperimen One Group Pretest-Posttest Design. Sebelum melaksanakan pembelajaran dilaksanakan tes awal (pretest) O1, dan setelah melaksanakan pembelajaran Guided Inquiry X dilakukan tes akhir (posttest) O2. Variabel yang diamati dalam penelitian adalah (1) Validitas RPP, BAS, LKS, LP dan Web Moodle. (2) Tingkat keterbacaan BAS, LKS dan Web Moodle. (3) Tingkat kesulitan BAS, LKS, dan Web Moodle. dan tes hasil belajar. (4) Variabel yang berkaitan dengan hasil ujicoba perangkat pembelajaran meliputi: keterlaksanaan RPP, ketepatan perangkat RPP, BAS, LKS, LP dan Web Moodle, aktivitas siswa, aktivitas guru, peningkatan hasil belajar siswa, respons siswa dan hambatan- hambatan selama kegiatan belajar mengajar.

Instrumen yang digunakan dalam penelitian ini adalah instrumen penilaian perangkat, instrument pengamatan, instrument tes, dan instrument angket. Data yang dianalisis adalah validitas perangkat, kepraktisan perangkat, dan keefektifitas perangkat dengan menggunakan teknik analisis deskriptif kulitatif.

\section{HASIL DAN PEMBAHASAN}

Penelitian ini dilaksanakan pada 84 siswa kelas XI IPA SMA Negeri 16 Surabaya materi termodinamika pada semester genap tahun pelajaran 2012/2013. Perangkat yang dikembangkan dalam penelitian meliputi 1) Validitas Perangkat Pembelajaran. (a) Kebenaran Konseptual Perangkat Pembelajaran, diperoleh nilai rata-rata validasi perangkat RPP dari dua validator yaitu 3,5 dengan persentase reliabilitas $85,71 \%$ sehingga RPP yang disusun berkategori reliabel.

Perangkat RPP ini disusun berdasarkan sintaks model pembelajaran Cooperative dalam pendekatan blended learning sehingga siswa dengan siswa dan siswa dengan guru bisa berkomukasi melalui Web Moddle (Dwiyogo, 2011). Perangkat LKS siswa download pada web moodle yang sudah disediakan oleh guru, dari LKS I, LKS II dan LKS III, hasil validasi perangkat berkategori sangat baik dengan reliabilitas $75 \%$. Dengan demikian perangkat tersebut bisa dikatakan reliabel. Perangkat yang juga membantu siswa dalam belajar adalah BAS. Perangkat ini disusun sesuai dengan standar kompetensi dan kebutuhan siswa. hasil validasi perangkat BAS termasuk dalam kategori baik dengan realibilitas 77,27\% sehingga bisa dikatakan bahwa BAS reliabel. Perangkat yang menjadi sarana pendekatan pembelajaran adalah Web Moodle dengan homepage http://fisikaunesa.net.elearning/, yang divalidasi oleh pakar IT dengan rata-rata 3,8 berada dalam kategori baik, Dalam web moodle peneliti telah menyediakan sarana belajar, seperti Flash, BAS, LKS, Phet, ebook dan soal-soal latihan, siswa tinggal mendownload bahan ajar tersebut, apabila ada siswa yang tidak login, peneliti sudah menyiapkan di luar yaitu di navigation. (b) Tingkat Keterbacaan LKS, BAS dan Web Moodle, Penilaian tingkat keterbacaan LKS, BAS Web Moodle menggunakan persentase jumlah berdasarkan jumlah jawaban siswa yang benar. Dari hasil penilaian yang diberikan terhadap 14 orang siswa pada Tabel 4.10 diperoleh rata-rata tingkat keterbacaan untuk LKS yaitu 99\% dan untuk BAS adalah 97,7\% serta web moodle adalah 100\%. Hasil tersebut menunjukkan bahwa baik tingkat keterbacaan LKS, BAS maupun web moodle berada pada kategori mudah untuk dipahami.(c) Tingkat Kesulitan LKS, BAS, Web Moodle dan Tes Hasil Belajar, diperoleh rata-rata tingkat kesulitan untuk LKS yaitu rata-rata 13,1 dan untuk BAS adalah 1,0 serta web moodle adalah 0,0. Hasil tersebut menunjukkan bahwa baik tingkat kesulitan LKS, BAS maupun web moodle berada pada kategori rendah atau sangat mudah untuk dipahami. 2) Diskusi Hasil Kepraktisan Perangkat Pembelajaran. (a) Rencana pelaksanaan pembelajaran disusun sesuai dengan jumlah tatap muka untuk proses pembelajaran yaitu tiga kali pertemuan. Setiap pertemuan dalam KBM, pelaksanaan RPP diamati oleh dua pengamat yang mengamati berlangsungnya proses pembelajaran. Persentase 
pelaksanaan RPP pada kelas IPA 2, IPA 3 dan IPA 4 tidak ada perbedaaan diperoleh $100 \%$ terlaksana dengan kategori sangat baik. Pengamatan aktivitas siswa dilakukan selama proses pembelajaran berlangsung oleh dua orang pengamat.

Dari hasil pengamatan menunjukan bahwa persentase rata-rata aktivitas kelas yang dominan pada kelas IPA 2 mendwonload LKS, BAS, Phet, Flash pada moodle, sedangkan untuk mempresentasikan dan diskusi rata-rata dari 27 siswa hanya 20 siswa yang aktif dengan persentase $91,1 \%$, pada kelas IPA 3 hampir sama dengan siswa kelas IPA 2 lebih dominan mendwonload LKS, BAS, Phet, Flash pada moodle, terdapat 21 siswa yang tidak menyimpulkan hasil diskusi dengan persentase 92,3\% dan pada kelas IPA 4 sama juga seperti dua kelas sebelumnya, lebih dominan mendwonload LKS, BAS, Phet, Flash pada moodle, dari 29 siswa ada 22 siswa yang tidak mendengar penjelasan guru dengan persentase $87,4 \%$. Persentase yang paling rendah adalah kelas IPA 4, karena jam fisika setelah istirahat, jadi ada beberapa siswa yang telat masuk kelas. Secara keseluruhan siswa kelas IPA 2, IPA 3 dan IPA 4 melakukan aktivitas yang menjukkan persentase $100 \%$ adalah mendwonload LKS, BAS, Phet, Flash pada moodle, membentuk kelompok, membaca LKS, merumuskan hipotesis, menuliskan variabel manipulasi dan respon.

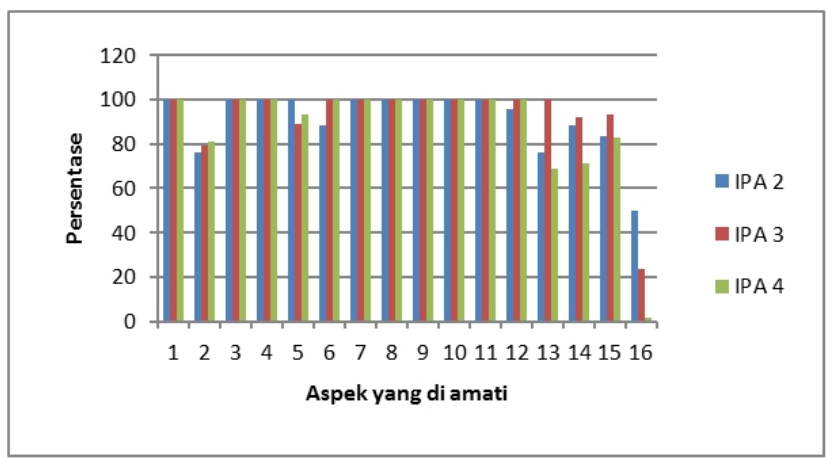

Gambar 3.1 Grafik rata-rata aktivitas tiga kelas XI

Beberapa kendala yang terekam oleh pengamat. Kendala-kendala tersebut berasal dari siswa dan sarana sekolah itu sendiri. Dilihat dari sisi sarana dan prasarana sekolah, SMA Negeri 16 Surabaya diantaranya adalah lemahnya jaringan WIFI, tidak semua siswa mempunyai laptop, kurangnya memory pada web moodle. 3) Diskusi Hasil Keefektivitas Perangkat Pembelajaran. (a) Hasil belajar yang dianalisis dalam penelitian ini adalah hasil belajar produk dan hasil belajar proses. Pembelajaran blended learning model cooperative ini dapat dikatakan berhasil ketika hasil belajar siswa menunjukkan ketuntasan di atas nilai KKM yaitu 75. Rata-rata hasil belajar kognitif produk dari hasil uji coba lapangan pada 3 kelas X dapat dilihat pada Gambar 3.1 Rata-rata nilai hasil belajar kognitif produk yang diperoleh setiap kelas uji coba berada diatas KKM dengan nilai berada pada interval antara 91-92.

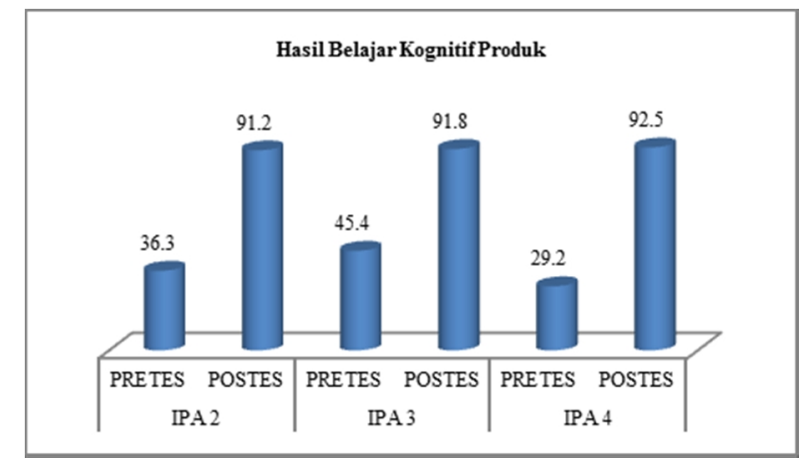

Gambar 3.2 Grafik rata-rata hasil belajar kognitif produk tiga kelas XI

Rata-rata hasil belajar kognitif proses dari uji coba lapangan pada 3 kelas XI dapat dilihat pada Gambar 3.2 Dari gambar terlihat bahwa rata-rata hasil belajar kognitif proses berada diatas nilai KKM seperti halnya hasil belajar kognitif produk yaitu pada interval 90-92.

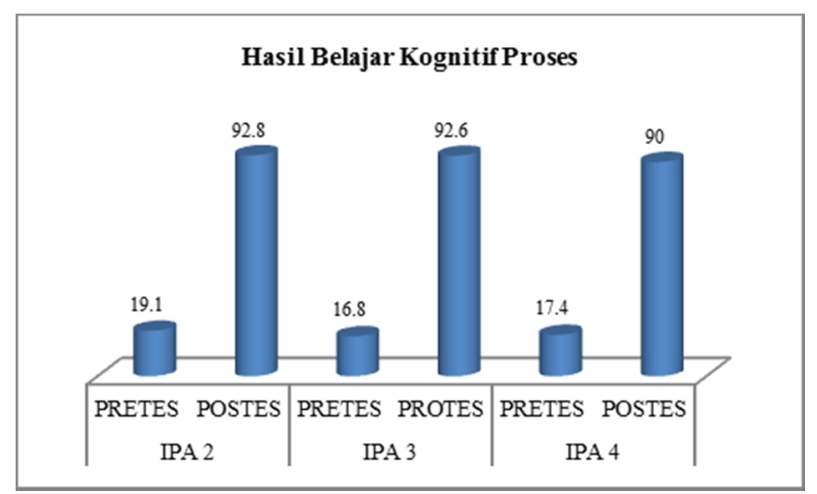

Gambar 3.3 Grafik rata-rata hasil belajar kognitif proses tiga kelas XI.

Hasil belajar kognitif produk untuk siswa kelas XI IPA 2, XI IPA 3 dan XI IPA 4 SMA Negeri 16 Surabaya pada Gambar 4.5, 4.6 dan 4.7 menunjukkan saat pretes semua siswa dinyatakan tidak tuntas dan semua nilai di bawah standar karena belum diajarkan menggunakan pembelajaran blended learning model cooperative, namun, saat postes semua siswa tuntas dan mendapat nilai tinggi di atas KKM pada hasil belajar produk, kemudian peningkatan nilai hasil belajar menggunakan N-Gain skor menunjukkan peningkatan yang Tinggi, pembelajaran yang berada pada skala nilai $0,7-0,1$ berada pada kategori tinggi (Hake, 1999). Pada kelas IPA 2 dengan rata-rata 0,88 berada pada kategori tinggi, pada kelas IPA 3 dengan ratarata 0,85 berada pada kategori tinggi dan terakhir kelas IPA 4 dengan rata-rata 0,87 berada pada kategori Tinggi, hal ini karena siswa sangat paham dengan konsep materi termodinamika yang diajarkan oleh guru, dari hasil rata-rata secara klasikal, kelas IPA 2 lebih tinggi nilainya di ikuti oleh IPA 4 dan IPA 3, peneliti menilai bahwa IPA 2 lebih 
konsen dan berkooperatif tinggi dalam belajar. (Primasari, 2011) menyimpulkan bahwa pembelajaran yang menggunakan blended learning dapat meningkatakan hasil belajar siswa sehingga dapat memenuhi standar ketuntasan kelulusan (SKL) yang ditetapkan oleh sekolah dan sesuai hasil penelitian (Rovai dan Jordan, 2004) pembelajaran blended learning menghasilkan perasaan berkomunitas lebih kuat antar siswa sehingga pembelajaran jauh lebih menyenangkan sehingga penguasaan materi akan lebih mudah.

\section{PENUTUP SIMPULAN}

Berdasarkan hasil penelitian dan pembahasan dapat disimpulkan bahwa Pengembangan Perangkat pembelajaran blended learning model cooperative untuk meningkatkan hasil belajar fisika SMA kelas XI yang memenuhi kriteria validitas, kepraktisan dan keefektivitas layak digunakan.

\section{DAFTAR PUSTAKA}

Amiroh. 2012. Kupas Tuntas Membangun E-Learning Dengan Moodle. Genta Gropus Production: Sidoarjo.

Bersin, Josh. 2004. The Blended Learning Book: Best Practices, Prov En Methodologies, and Lesson Learned. Copyright by Jhon woly and Son. San Francisco.

Bonk, C. (2006) Blended Learning: situations and solutions. Presentation to Oxford Brookes University (online). Available from.

BNSP. 2007. Standar Isi untuk Satuan Pendidikan Dasar dan Menengah. Jakarta

Dwiyogo D. Wasis. 2011. Pembelajaran berbasis blended learning.

(Online). (http://id.wikibooks.org/w/index.php?title=Pembelajar an_Berbasis_Blended_Learning\&printable=yes. diakses tanggal 1 Desember 2011).

Dziuban.D. Charles. Blended learning. Educause center for applied research.vol. 2004, Issue 7, March 30, 2004, 80301-2538.

Fitria, Rizca. 2011. Blended Learning. (Online). (http://rizcafitria.wordpress.com/, diakses tanggal 15 Oktober 2011).

Giancoli, D.C. 2009. Physich for scientists \& Engineers with Modern Physics. New Jersey: Pearson Prentice Hall.

Hake, R.R. 1999. American Educational Research Association's Division D, Measurement and research Methodology: analyzing Change/Gain Scores, USA: Woodland Hills

Hoic-bozic, Natasa (2009), A Blended Learning Approach to Course and Implementation, IEEE Transactions on Education, Vol. 52.
Johnson, D., \& Johnson, R. (1992). Positive interdependency: Key to effective cooperation. In R. Hertz-Lazarowitz \& N. Miller (Eds.), Interaction in cooperative groups: The theoretical anatomy of group learning (pp. 174-199). Cambridge: Cambridge University Press.

Kemp, J E., Morrison R. And Ross, Gary R. 2007. Designing Effevtive Instruction 5Th Edition. USA: Macmillan College Publishing Company.

Kusairi, Sentot. 2011. Implementasi Blended Learning dalam Pembelajaran. Makalah. Disajikan dalam Seminar Nasional 2011 dengan Tema Pengembangan Pembelajaran Blended Learning di Universitas Negeri Malang.

Purwaningsih dyah, Pujianto. 2009. Blended Coopeative ELearning (Bcel) Sebagai Sarana Pendidikan Penunjang Learning Community. Makalah. Disajikan dalam Seminar Nasional 2009 dengan Tema Peranan ICT (information and communication tecnology) dalam pembelajaran di Universitas Negeri Yogyakarta

Program Pascasarjana. 2012. Pedoman Penulisan Tesis dan Disertasi. Surabaya: Pascasarjana Unesa.

Ratumanan \& Laurens. 2006. Evaluasi Belajar yang relevan dengan KBK. Unesa Universitas Press. IKAPI: Surabaya.

Rooney, J. E. 2003, Blended learning opportunities to enhance educational programming and meetings. Association Management, 55(5), 26-32.

Thorne, Kaye. 2003. Blended learning: How To Integrate Online And Traditional Learning. USA. 